\title{
Insulin and Glucagon Secretion in Diabetic and Non-Diabetic Patients with Circulating Islet Cell Antibodies*
}

\author{
A. Tiengo ${ }^{1}$, G. F. Del Prete ${ }^{2}$, R. Nosadini ${ }^{1}$, C. Betterle ${ }^{2}$, C. Garotti ${ }^{1}$, and G. Bersani ${ }^{2}$ \\ ${ }^{1}$ Department of Internal Medicine, Division of Gerontology and Metabolic Diseases, and ${ }^{2}$ Semeiotica Medica, University of Padua, \\ Padua, Italy
}

\begin{abstract}
Summary. Thirty-nine patients (14 non-diabetics, 8 chemical diabetics, and 17 overt diabetics) with circulating islet cell antibodies (ICA) were studied. Insulin and glucagon secretion after oral $(100 \mathrm{~g})$ and intravenous glucose loading $(200 \mathrm{mg} / \mathrm{kg}$ bolus injection followed by an infusion of $20 \mathrm{mg} / \mathrm{min}$ over $60 \mathrm{~min}$ ) and arginine infusion ( $25 \mathrm{~g}$ over $30 \mathrm{mi}-$ nutes) were evaluated in these patients and in non diabetic and diabetic ICA-negative controls. In the non-diabetic groups with or without ICA, insulin and glucagon responses to glucose were similar. Moreover, in ICA positive patients the response of these hormones to arginine infusion was reduced. Similar alterations in insulin and glucagon secretion were observed in the ICA positive and negative patients with chemical or overt diabetes. In particular, fasting hyperglucagonaemia and glucagon hyperresponse to arginine are associated with a lack of insulin secretion in the patients with overt diabetes. Hormonal differences between diabetics with and without ICA could not be detected.
\end{abstract}

Key words: Diabetes, autoimmunity and diabetes, islet cell antibodies, insulin and glucagon secretion, glucose and arginine infusion.

The clinical and serological association between diabetes mellitus and organ-specific autoimmunity has been studied by various authors $[12,20,21,25]$. Recently, circulating islet-cell autoantibodies (ICA) were detected in a number of diabetics with as-

* This work was previously presented at the 12th Meeting of the European Association for the Study of Diabetes, Helsinki, September 1976 and published in abstract form in Diabetologia 12, 422 (1976) sociated polyendocrine autoimmune disorders [2, 17]. These antibodies were later observed in many cases of juvenile diabetes of recent onset, not associated with endocrinopathies $[13,16]$. ICA have also been reported in a small percentage of both maturity-onset and chemical diabetics and in some non-diabetics affected with one or more autoimmune disorders $[6,13]$.

The presence of specific islet-cell autoimmune activity, as suggested by circulating ICA, might play an important role in the development of the diabetic $\beta$ cell alteration. It has not yet been demonstrated if ICA are associated with or are responsible for the anatomical and functional damage of islet cells.

ICA have been demonstrated not only in diabetics but also in subjects with normal glucose tolerance [6]; in some cases the detection of ICA preceded the development of diabetes $[2,6]$.

The purpose of this work was twofold: to determine if ICA are always associated with functional islet-cell damage and if, in ICA positive diabetics, the lack of insulin secretion is associated with reduced glucagon production. The hypothesized reduction in glucagon secretion might be due to a coexisting involvement of both beta and alpha cells. This was suggested by Bottazzo et al. [2] on the basis of the immuno-fluorescent pattern produced by ICA, which seem to react against all the islet cells.

\section{Materials and Methods}

Thirty-nine patients with ICA were studied. These subjects were selected from a large group originally compiled for an epidemiological study [7] and successively divided into 3 sub-groups on the basis of their metabolic status, according to Fajans' criteria 
[8]. Group 1: 14 subjects with normal glucose tolerance, Group 2: 8 subjects showing normal fasting glucose levels and impaired glucose tolerance (chemical diabetes), Group 3: 17 patients with fasting hyperglycaemia and overt, poorly controlled diabetes (13 of the last were being treated with insulin and 4 with oral antidiabetic drugs).

The principal clinical and metabolic data of these patients are presented in Table 1.

A control group of 31 subjects, in whom ICA were not detected, was also studied. These were similarly divided into 3 groups on the basis of their glucose tolerance. Group 1: 15 subjects with normal glucose tolerance, Group 2: 8 subjects with chemical diabetes, and Group 3: 8 subjects with overt diabetes (Table 2).

Both patients and controls were studied during a hospital stay or through our out-patient clinic and were asked to follow a balanced diet containing at least $250 \mathrm{~g} /$ carbohydrate daily for at least 2 weeks prior to testing. Use of insulin and antidiabetic oral drugs was interrupted 24 hours before testing.

The following tests were carried out in the ICA positive patients and in the ICA negative controls:

- Oral Glucose Tolerance Test: (100 g) (not carried out in the patients with overt diabetes). Blood samples were collected at $0,30,60,90,120,180$, and 240 minutes.

- Intravenous Glucose Test (according to Cerasi and Luft [4]; not carried out in subjects with overt diabetes). A rapid bolus of $200 \mathrm{mg} / \mathrm{kg}$ was injected followed by an infusion of $20 \mathrm{mg} / \mathrm{min}$ over $60 \mathrm{mi}-$ nutes. Blood samples were taken at $0,5,10,30,40$, 60, 90, and 120 minutes.

- Arginine Infusion: $25 \mathrm{~g}$ of L-arginine monochlorhydrate, diluted in $100 \mathrm{ml}$ saline solution was infused over 30 minutes. Blood samples were collected at $0,5,15,30,45,60$, and 90 minutes.

All samples were collected in chilled test tubes containing EDTA $(1.2 \mathrm{mg})+$ Trasylol $(500 \mathrm{U})$ for $1 \mathrm{ml}$ of blood and rapidly centrifuged in the cold. Plasma was immediately frozen and stored at $-20^{\circ} \mathrm{C}$. Glucose was measured by the method of Huggett and Nixon [11], immunoreactive insulin and glucagon were assayed according to the method of Herbert et al. [10] and Faloona and Unger [9], respectively. Glucagon was determined using K-30 antiserum supplied by Dr. Unger (Dallas). Insulin was not determined in the patients receiving insulin injections for more than one month prior to testing (with the exception of case numbers 3 and 9 of the ICA positive patients in whom insulin injections had been previously discontinued for a long period and reinstated no more than a month prior to the onset

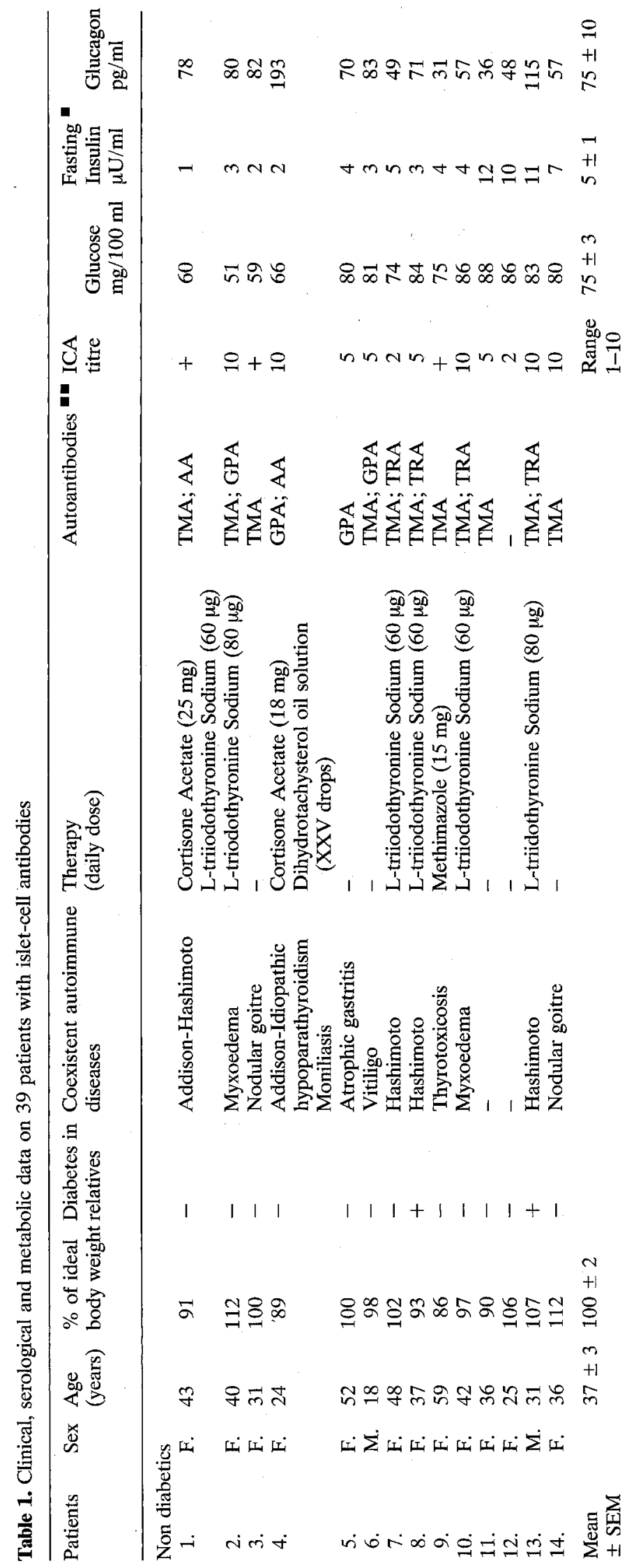




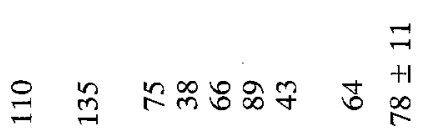

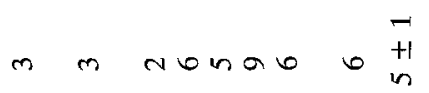

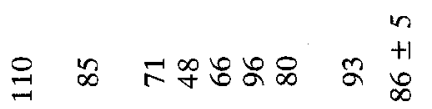

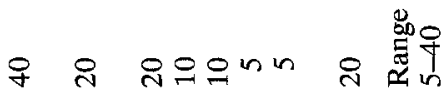

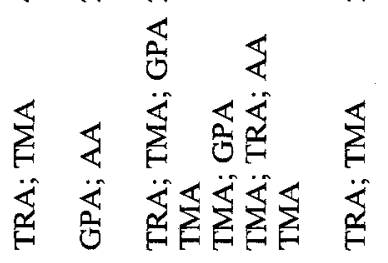

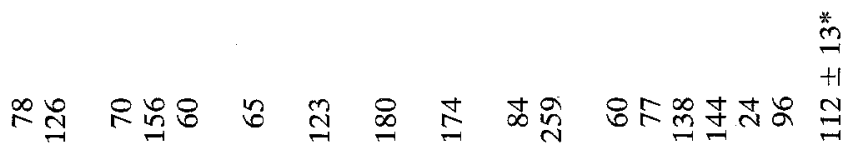
$0,0,1,0,+1, \infty, \infty-4-\infty \frac{n}{n}$

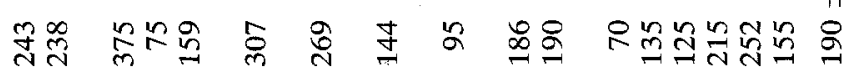

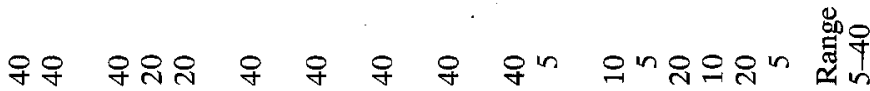

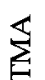

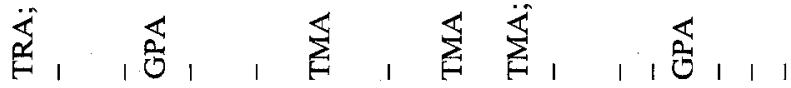
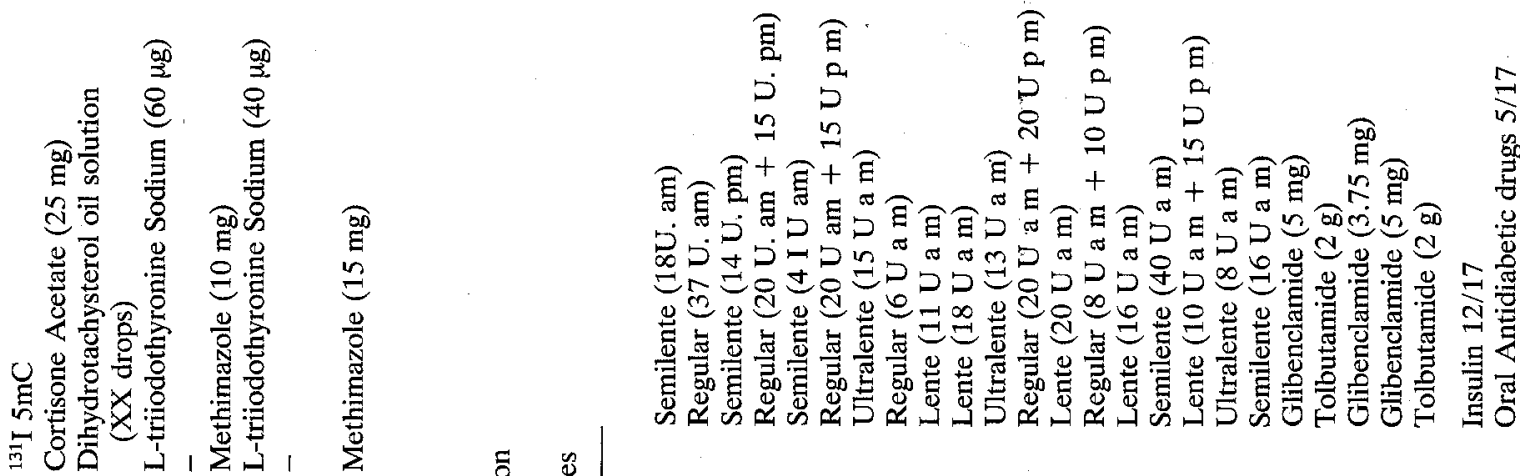

걱
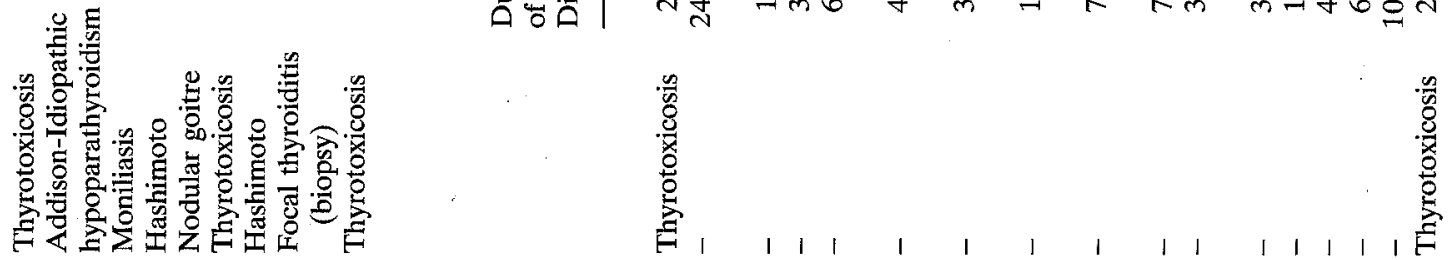

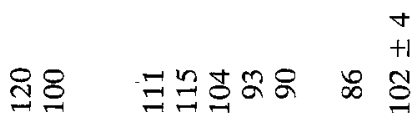

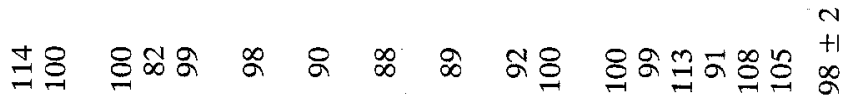

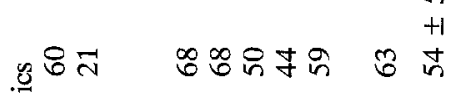

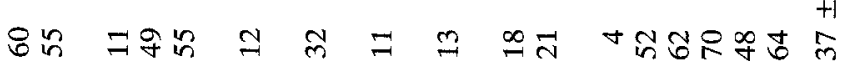

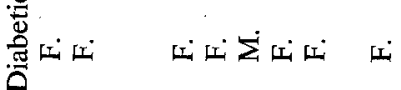

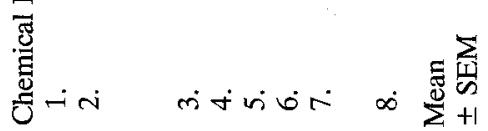


Table 2. Clinical and metabolic data on 31 patients without islet-cell antibodies

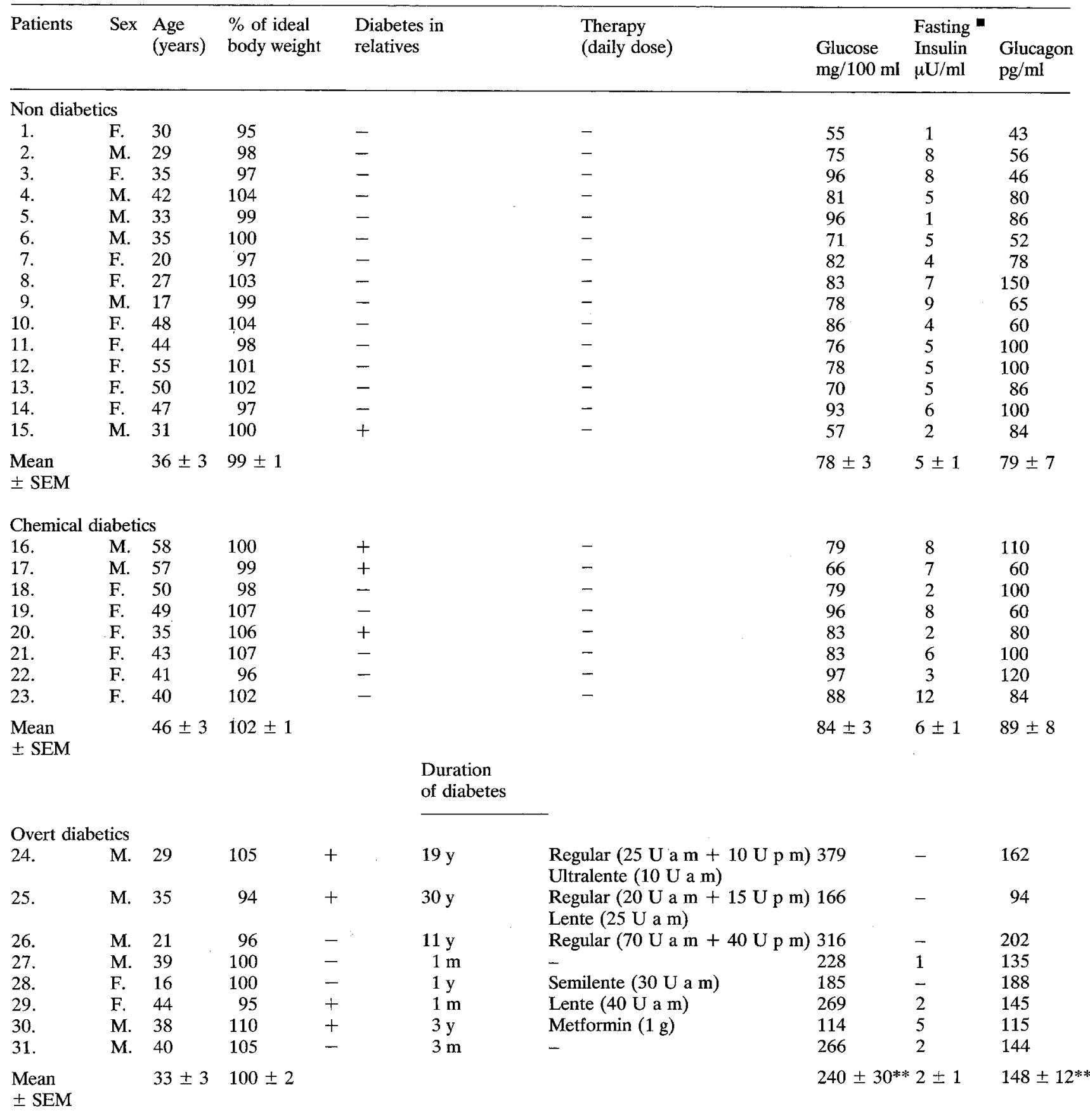

- = Values obtained from the mean of several determinations

$* *=p<0.001$ Significance between fasting values of overt diabetics and non diabetics

of our study). Glucose was determined the same day, insulin and glucagon within two weeks.

ICA were detected by the direct immunofluorescent technique using antihuman immunoglobulin fluorescein conjugate (Behringwerke, 1:3 diluted) according to Bottazzo et al. [2]. Fresh human pancreas was used as the tissue substrate for these experiments. All sera was also tested for antibodies to thyroglobulin, thyroid microsomal, adrenal and to parietal cells [24]. Sera was initially tested undiluted on the pancreas for 30 minutes and at 1:5 on other substrates. Titres were established by repeating the sandwich test with serial dilutions.

During arginine tests the area of the single variable above basal values was calculated. Statistical analysis was carried out using Student's " $t$ " test. 

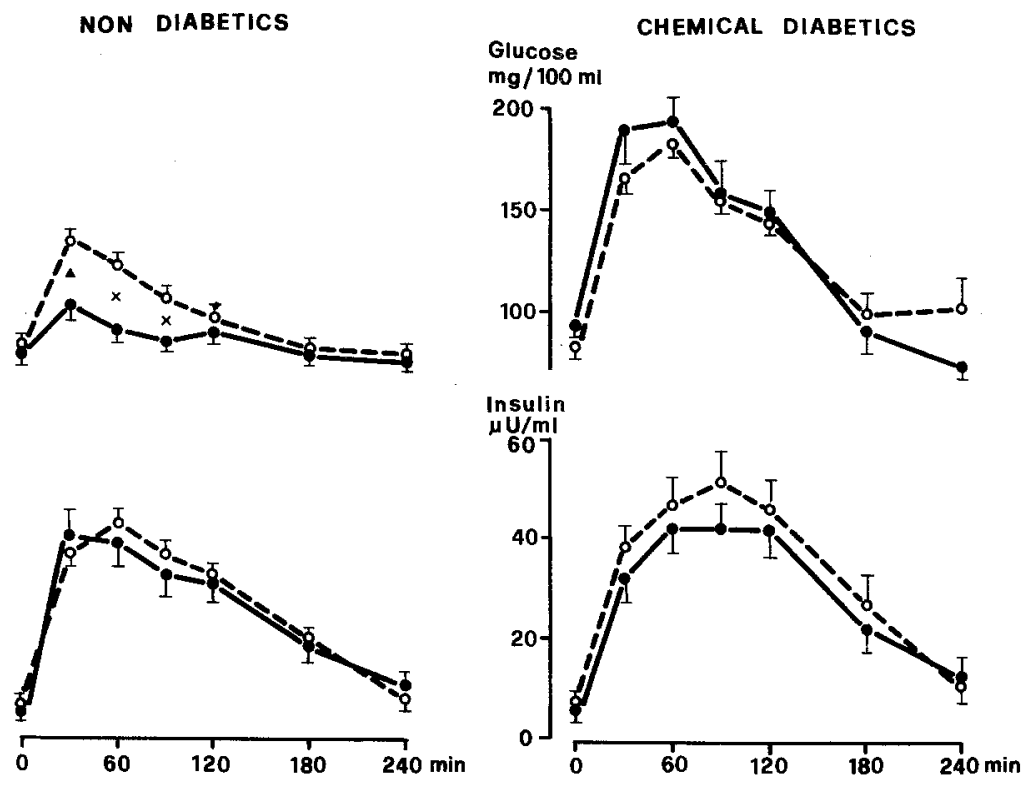

Fig. 1. Behaviour of glucose and insulin (Mean \pm SEM) after oral glucose tolerance test ( $100 \mathrm{~g}$ orally) in non-diabetics and in chemical diabetics with islet cell antibodies $(\mathrm{ICA}+)$ and in two control groups without $(\mathrm{ICA}-)$. The closed circles and solid line $(\bullet \bullet)$ represent the ICA + subjects while the open circles and dotted line (o---o) represent the ICA - subjects. Statistically significant differences are indicated by the symbols: $X(\mathrm{p}<0.01)$ and $\boldsymbol{\Lambda}(\mathrm{p}<0.001)$

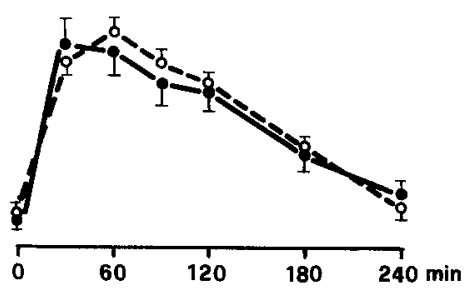

\section{Results}

\section{Plasma Glucose}

After oral glucose (Fig. 1) a mean flat glycaemic curve was observed in ICA positive non-diabetics. Glucose values were significantly lower at 30,60 , and 90 minutes with respect to the ICA negative patients.

Glucose values were similar in the ICA positive and negative chemical diabetics.

No significant difference (Fig. 2) was observed between ICA positive and negative subjects during the maximal hyperglycaemic phase of intravenous glucose infusion. Only at 90 minutes were significantly lower values observed in the ICA positive non-diabetics.

Glucose increase was significantly reduced at 15 , 30,45 , and 60 minutes of arginine infusion in ICA positive non-diabetics with respect to the control group (Fig. 3). No significant differences were observed during arginine infusion between the chemical diabetic groups or between the overt diabetic groups.

\section{Plasma Insulin}

Insulin fasting levels were similar in the patient and control groups. No significant difference was observed in insulin response to oral (Fig. 1) and intravenous glucose (Fig. 2) between ICA positive and negative subjects. Non-diabetic ICA positive patients, in fact, presented a normal early insulin secretion. In ICA positive and negative chemical dia- betics insulin secretion was reduced and delayed (Fig. 2).

During arginine infusion (Fig. 3) insulin response was significantly reduced at 30,45 , and 60 minutes in the non-diabetic ICA positive patients with respect to the controls. Insulin secretion, calculated as the area, was also significantly reduced $(\mathrm{p}<0.05)$. Progressive reduction in insulin secretion was present in chemical and in overt diabetes both in ICA positive and negative subjects. Insulin area measurements were consistent with this finding.

\section{Plasma Glucagon}

No significant difference in fasting levels was observed between respective ICA positive and negative subgroups. In both groups the deterioration of the metabolic condition was associated with an increase in glucagon levels (Tables 1 and 2). During hyperglycaemia following intravenous glucose infusion, glucagon behaviour was similar in ICA positive and negative subjects. A reduction in glucagon levels was observed in the non-diabetics. No reduction was reported in either of the groups with chemical diabetes in whom glucagon levels were never less than basal values (Fig. 2).

Glucagon response to arginine was slightly reduced in the ICA positive non-diabetics $(\mathrm{p}<0.05$ at $45 \mathrm{~min}$ ) with respect to the controls (Fig. 3). No significant difference, on the other hand, was observed in the response of glucagon and of its respective area in the groups with chemical or overt diabetes (Fig. 3). 


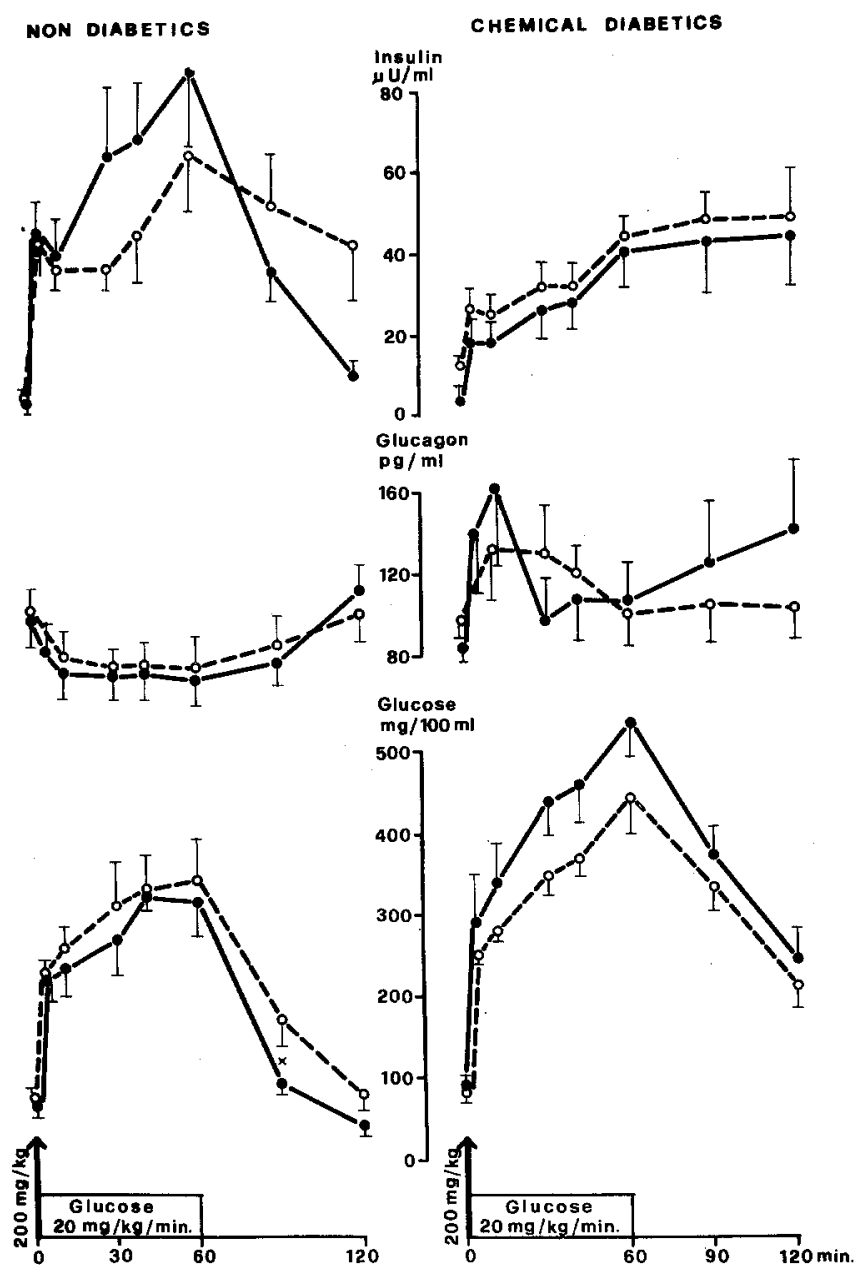

Fig. 2. Glucose, insulin, and glucagon behaviour (Mean \pm SEM) after IV bolus injection and IV. continuous glucose infusion in non-diabetic and chemical diabetic ICA+ patients and in two ICA - control groups. The closed circles and solid line (๑- $\bullet)$ represent the ICA + subjects while the open circles and dotted line $(0---O)$ represent the ICA- subjects. Statistically significant differences $(p<0.05)$ are indicated by the symbol $x$

\section{Discussion}

In non-diabetics the presence of circulating ICA does not seem to be associated with diabetic-like alterations of beta-cell function. In fact, the 14 patients with ICA and normal glucose tolerance showed normal insulin secretion after oral or intravenous glucose administration.

The finding of specific autoantibodies in the absence of overt deficiency of the target gland is not unusual in endocrine autoimmunity (thyroid or adrenal), and the discovery of autoantibodies may antedate the onset of endocrine impairment. ICA, therefore, might precede the onset of an anatomical and/or functional islet-cell alteration of the diabetic type, as observed in some cases [2,6]. Only a pro- spective study will be able to clarify whether the presence of ICA should be considered a marker of a prediabetic condition, as suggested recently by Irvine [14].

As regards alpha-cell function, normal fasting glucagon levels, normal suppression by hyperglycaemia, and reduced glucagon secretion during arginine infusion were observed in the ICA positive non-diabetics. Reduced glucagon response cannot be explained by alpha-cell damage due to a specific autoimmune process since ICA positive diabetics showed fasting and arginine-induced hyperglucagonaemia. In ICA positive non-diabetics, reduced alpha cell reactivity might partially explain the absence of arginine-induced hyperglycaemia. It would seem that the first phase of islet cell autoaggression is associated with an alteration in the responsitivity of beta and alpha cell membrane receptors to arginine. It is more difficult to explain the flat glycaemic curve after oral glucose observed in ICA positive non-diabetics. Nevertheless, "flat curves" at OGTT are reported in $25 \%$ of the general population with normal glucose tolerance [22] and may be observed more frequently in polyendocrine patients with adrenal or thyroid involvement, as in the majority of our non-diabetic subjects with ICA.

Neither overt nor chemical "autoimmune" diabetes show beta or alpha cell alterations different from those generally reported in diabetes mellitus. In fact, in our ICA positive patients the reduction of insulin secretion was in proportion to the rise in fasting glucagon levels and to the increase in alpha cell response to arginine also observed in ICA negative overt diabetics. "Autoimmune diabetes", therefore, cannot be classified among the diabetic conditions characterized by both beta and alpha cell anatomic-functional damage, such as diabetes secondary to pancreatectomy, chronic pancreatitis, or haemochromatosis $[1,23]$.

It has been observed that the ICA immunofluorescent pattern involves all of the islet cells. Moreover, diffuse anatomical alterations of the islet cells have been reported in experimental autoimmune insulitis [5]. It is also known that endocrine autoimmunity may be directed against more than one type of target-cells. These considerations seem to suggest that "autoimmune" diabetes could lead to a reduction in both insulin and glucagon production [2]. This hypothesis was not confirmed by fasting hyperglucagonaemia, lack of glucagon suppression during glucose infusion and arginine induced hyperglucagonaemia, common features of "genetic" diabetes $[18,26]$ or experimental diabetes obtained with anti-insulin antibodies, alloxan or streptozoto- 

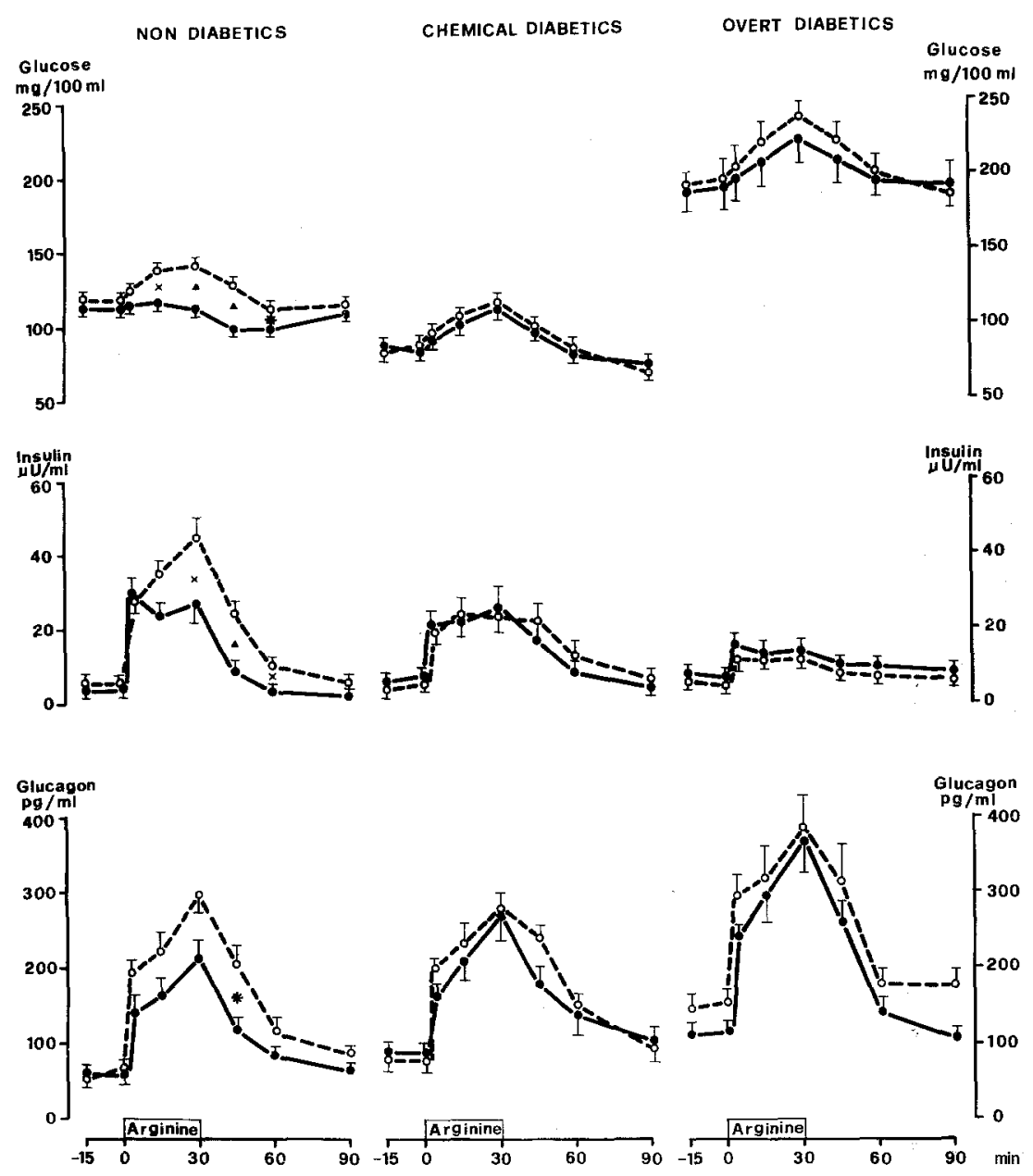

Fig. 3. Glucose, insulin and glucagon response to IV arginine infusion (Mean \pm SEM) ( $25 \mathrm{~g}$ over $30 \mathrm{~min})$ in non diabetic, chemical, and overt diabetic ICA + patients and in their respective ICA - control groups. The closed circles and solid line $(\bullet-)$ represent the ICA + subjects while the open circles and dotted line (o- - o) represent the ICA - subjects. Statistically significant differences are indicated by the simbols: * $(\mathrm{p}<0.05), \times$ $(\mathrm{p}<0.01), \Delta(\mathrm{p}<0.001)$

cin $[15,19]$. It is probable, therefore, that ICA are specific only for a beta-cell antigen, while in the immunofluorescent test they crossreact to antigenic components of other islet cells. However, specific alpha-cell autoantibodies do really exist and have been demonstrated. In some diabetics alpha cell antibodies may be associated with ICA [3]. It is only in the latter condition that a depression of alpha cell function might be associated with a diabetic condition.

Acknowledgements. The authors wish to thank Dr. Franco Rigon (Paediatric Clinic, University of Padua) for his valuable aid in compiling case reports and Miss Linda Inverso for translation and editing of manuscript. Special thanks are also extended to Prof. Mario Austoni and Prof. Gaetano Crepaldi for their interest and suggestions.

This work was supported in part by C.N.R. (Consiglio Nazionale delle Ricerche) grants CT 75.00636.04 and 75.00465 .04 .

\section{References}

1. Assan, R., Tiengo, A.: Comparisons des sécrétion de glucagon dans les diabètes sucrés avec ou sans pancréatopathie organique acquise. Pathol. Biol. (Paris) 21, 15-25 (1972)
2. Bottazzo, G. F., Christensen, A. F., Doniach, D.: Islet-cell antibodies in diabetes mellitus with autoimmune polyendocrine deficiencies. Lancet 1974 II, 1279-1282

3. Bottazzo, G. F., Lendrum, R.: Separate autoantibodies reacting with human pancreatic glucagon and somatostatin cells. Lancet 1976 II, 873-876

4. Cerasi, E., Luft, R.: Insulin response to glucose infusion in diabetic and non diabetic monozygotic twin pairs. Genetic control of insulin response. Acta Endocrinol. (Kbh) 55, 276-304 (1967)

5. Craighead, J.E.: Insulitis associated with viral infection. In: P.A. Bastenie, W. Gepts (Eds.): Immunity and Autoimmunity in Diabetes Mellitus, p. 227-233. Amsterdam: Excerpta Medica 1974

6. Del Prete, G.F., Tiengo, A., Bersani, G., Nosadini, R., Toffolo, A., Betterle, C., Garotti, C., Trisotto, A.: Insulin and glucagon secretion in patients with pancreatic islet-cell antibodies, p. 324. Abstracts - 5th International Congress of Endocrinology, Hamburg, July 18-24, 1976

7. Del Prete, G.F., Padovan, D., Erle, G., Toffolo, A., Bersani, G.: Islet cell antibodies in diabetes mellitus. Diabetes (in press)

8. Fajans, S.S., Conn, J.S.: The early recognition of human diabetes mellitus. Ann. N. Y. Acad. Sci. 82, 208 (1959)

9. Faloona, G. R., Unger, R.H.: Glucagon. In: B.M. Jaffe, H. R. Behrmann (Eds.): Methods of Hormone Radioimmunoassay, p. 317-330. New York, London: Academic Press 1974 
10. Herbert, V., Kam-Seng, L., Gottlieb, C.W., Bleicher, J.: Coated charcoal immunoassay of insulin. J. Clin. Endocrinol. 25, 1375-1384 (1965)

11. Huggett, A., Nixon, D.A.: Use of glucose oxidase, peroxidase and $\mathrm{O}$-dianisidine in the determination of blood and urine glucose. Lancet 1957 II, 368-370

12. Irvine, W.J., Clarke, B. F., Scarth, L., Cullen, D. R., Duncan, L.J.P.: Thyroid and gastric autoimmunity in patients with diabetes mellitus. Lancet 1970 II, 163-168

13. Irvine, W.J., Gray, R.S., McCallum, C.J., Campbell, C.J., Duncan, L.J.P., Farquhar, J.W., Morris, P.J.: The prevalence of serum pancreatic islet cell antibodies in diabetes mellitus according to age at onset, insulin dependence and duration of diabetes and HL-A type, p. 221. Abstracts - 5th International Congress of Endocrinology, Hamburg, July $18-24,1976$

14. Irvine, W.J., Gray, R.S., McCallum, C.J.: Pancreatic isletcell antibody as a marker for asymptomatic and latent diabetes and prediabetes. Lancet 1976 II, 1097-1102

15. Katsilambros, N., Rahman, Y. A., Hinz, M., Fussgänger, R. Schröder, K.E., Straub, K., Pfeiffer, E. F.: Action of streptozotocin on insulin and glucagon responses of rat islet. Horm. Metab. Res. 2, 268-270 (1970)

16. Lendrum, R., Walker, G., Gamble, D.R.: Islet-cell antibodies in juvenile diabetes mellitus of recent onset. Lancet 1975 I, $880-883$

17. MacCuish, A.C., Barnes, E.W., Irvine, W.J., Duncan, L.J.P.: Antibodies to pancreatic islet cells in insulin dependent diabetics with coexistent autoimmune disease. Lancet 1974 II, 1529-1531

18. Müller, W.A., Faloona, G.R., Aguilar-Parada, E., Unger, R.H.: Abnormal alpha cell function in diabetes: response to carbohydrate and protein ingestion. N. Engl. J. Med. 283, 109-115 (1970)

19. Müller, W.A., Faloona, G.R., Unger, R.H.: The effect of experimental insulin deficiency on glucagon secretion. J. Clin. Invest. 50, 1992-1999 (1971)
20. Nerup, J., Anderson, O. O., Bendixen, G., Egeberg, J., Gunnarson, R., Kromann, G., Poulsen, J.E.: Cell-mediated immunity in diabetes mellitus. Proc. R. Soc. Med. 67, 506-513 (1974)

21. Nerup, J.: The clinical and immunological association of diabetes mellitus and Addison's Disease. In: P.A. Bastenie, W. Gepts (Eds.): Immunity and Autoimmunity in Diabetes Mellitus, p. 149. Amsterdam: Excerpta Medica 1974

22. Nolan, S., Stephan, T., Khurana, R.C., Morgan, C. R., Danowski, T.S.: Low profile (flat) glucose tolerances. Am. J. Med. Sci. 264, 33-39 (1972)

23. Persson, I., Gyntelberg, F., Heding, L. G., Boss-Nielsen, J.: Pancreatic glucagon-like immunoreactivity after i. v. insulin in normals and chronic-pancreatitis patients. Acta Endocrinol. (Kbh) 67, 401-408 (1971)

24. Roitt, I., Doniach, D.: Manual of autoimmune serology, pp. 1-8. W. H.O. (Ed.) Geneva, 1969

25. Ungar, B., Stocks, A.E., Martin, F.I.R., Whittingham, S., Mackay, I. R.: Intrinsic-factor antibody, parietal-cell antibody and latent pernicious anemia in diabetes mellitus. Lancet $1968 \mathrm{I}, 415-424$

26. Unger, R.H., Aguilar-Parada, E., Müller, W., Eisentraut, A. M.: Studies of pancreatic alpha cell function in normal and diabetic subjects. J. Clin. Invest. 49, 837-848 (1970)

Received: December 13, 1976, and in revised form: April 14, 1977

Prof. Antonio Tiengo

Department of Internal Medicine

Division of Gerontology and Metabolic Diseases

University Hospital

Via Giustiniani 2

I-35100 Padova

Italy 